\title{
Navigating the unequal education space in post-9/11 England: British Muslim girls talk about their educational aspirations and future expectations
}

\author{
Farzana Shain \\ Goldsmiths, University of London
}

\begin{abstract}
This paper explores educational inequalities through an analysis of the educational aspirations and future expectations of British girls and young women who identify as Muslim. It draws on qualitative interviews and focus group discussions with teen girls (aged 13-19) and young women in their early 20s living in the north and south of England, the first generation to be considering their future options in the immediate aftermath of the Brexit referendum. The analysis reveals contradictions at the heart of the UK education system in that while girls are being encouraged to aim high, to be aspirational and successful, they are also tasked with accepting responsibility for the structural and racialised disadvantage that prevents many Muslim women from translating educational success into labour market advantage. The priority given to educational attainment within the current UK education system leaves little space to prepare young women to deal with the potential disadvantage they may face in the labour market. When it comes to the racialised disadvantage that Muslims and minorities face in a post-9/11 and post Brexit referendum climate, the research revealed gaps and silences which have the effect of responsibilising Muslims students for terrorist incidents when they occurred.
\end{abstract}

Keywords: British Muslim girls; aspirations; neoliberal education; 9/11; Brexit

\section{Introduction}

This paper explores educational inequalities through an analysis of the educational aspirations and future expectations of British girls and young women who identify as Muslim. 
Recent policy and research reports have pointed to the 'broken promise of social mobility' for young Muslims in the UK (Social Mobility Commission, 2016; Stevenson, Demack, Stiell, Abdi, Ghaffar and Hassan, 2017). Statistics show that young people from Pakistani and Bangladeshi backgrounds (the largest Muslim ethnic groups in the UK) are more likely than ever to succeed in education and go on to university than other groups - particularly girls. However, they continue to experience poorer labour market outcomes than non-Muslims as well as enduring significant disadvantages across a number of areas, including housing and health (JRF, 2017).

Muslim women, in particular, have poorer opportunities when it comes to the labour market. They are three times more likely than the general population to be recorded as 'looking after home and family' (Ali, 2015). The reasons for this economic inactivity are not just cultural as is often assumed within policy reports and discourses (Cantle, 2001; Casey, 2016) but structural - they include factors such as the type of work available, childcare access, and the bias and discrimination that ethnic and religious minorities face during the selection process and once in post (Women's Budget Group, 2017). When Muslim women of Pakistani and Bangladeshi origin do work, they often earn less than their counterparts (Social Mobility Commission, 2016).

Alongside and intersecting with this structural disadvantage, the political discourse linking Islam and terrorism, especially since 9/11, has had particular material consequences for Muslims. Girls and women, especially those who are visibly Muslim because they wear Islamic forms of dress such as the hijab, jilbab or niqab, have been at the sharp end of the cultural and political hostility that has arisen on the back fears about Islamist extremism in the era of the war on terror. Reports of visibly Muslim women being targeted, for example, through having their hijabs forcibly pulled off, have been increasing. Metropolitan Police figures released in 2016, showed that the number of hate crimes targeting Muslims in London increased by $59.4 \%$ between 2015 and 2016 while the Greater Manchester Police force noted an increase in similar crimes of 96\% between November 2014 and October 2015 (cited in Women and Equalities Committee Report, 2016). The Home Office (2018) reporting on data collected across 44 police forces in England and Wales, recorded a total of 2,965 incidents targeting Muslims in 2017/8. This comprised 52\% of the offences in that year, higher than for 
any other religious minority in the UK. In 2018/19 the number of religiously motivated hate crimes reportedly targeting Muslims was marginally smaller as a total proportion of the offences recorded for that year at $47 \%$ but had risen to 3,530 (Home Office, 2019) showing an increase in the total number of offences being reported to police by Muslims. While the figures could signal increased confidence in reporting and better mechanisms for recording these events, there have also been some notable spikes following incidents such as the London and Manchester terror attacks in 2017 and in the weekend following the EU membership referendum in 2016 (Tell MAMA, 2017). Further spikes were noted in connection with the 'Punish a Muslim Day' letters in March and April 2018 and following the former Foreign Secretary Boris Johnson's comments in his Telegraph column in August 2018 in which he compared veiled Muslim women to 'letterboxes' and 'bank robbers'. Tell MAMA's reports confirm that the majority of religiously motivated hate incidents (both at street level and online) are committed against Muslim women, that the perpetrators are mostly white men and that the number of incidents is rising (Tell Mama, 2019).

This paper explores how British Muslim girls define their educational aspirations and future expectations against the background of this continuing socio-economic disadvantage and increasing cultural and political hostility. The research is also set in the context of the changing parameters of education and labour market requirements. The current emphasis on academic attainment and 'raising standards' within education, builds on the neoliberal restructuring started in the 1970 s as a response to industrial and manufacturing decline. As under-employment and insecure jobs become the norm, successive government policies (since 1990s, in particular) have tasked young people to 'raise their aspirations' as a way to offset the risks associated with economic and social uncertainties following the crash of 2008, and now with the expectation of Brexit; the structural inequalities that shape the life chances of young people are often overlooked in neoliberal policy-making (Pimlott-Wilson, 2015).

Within schools and colleges, Muslim students are increasingly being viewed through the lens of counterterrorism as a threat to the social order (Miah, 2017; Mac an Ghaill and Haywood, 2017; Shain , 2017). For Muslim girls this means that at the same time as being encouraged to be aspirational, to work hard and achieve academically, they are also constructed as Muslim girls, to be potentially risky and dangerous and in need of regulation and surveillance 
(Shain , 2013; Meetoo and Mirza, 2018). While organised within a safeguarding framework, the government's prevent duty ${ }^{1}$ which came into force in 2015 , has been criticised for targeting and stigmatising Muslim students, primarily (Kundnani, 2009; Shain , 2013). The requirement on schools to 'actively promote' the 'fundamental British Values' (FBV) ${ }^{2}$ also places a burden on Generation 9/11 Muslim students to continually prove their loyalty to the British state while it remains unclear what is distinctly British about the so-called FBV (Lander, 2017; Vincent, 2019). All of these factors potentially shape and impact the current experiences and future expectations of Muslim girls.

Against this background, the paper sets out to explore how a new generation of Muslim girls navigate the unequal education space in considering their futures. The paper contributes to a growing body of work that explores how the high aspirations for educational success of often disadvantaged Muslim women can be understood and theorised (Ahmed, 2001; Shah, Dwyer and Modood 2010; Bagguley and Hussain, 2016; Khattab and Modood, 2018). It seeks to extend these analyses by focusing on how Muslims young women's aspirations and expectations are being shaped in the current period of social, political and economy uncertainty. In doing so, the paper contributes new empirical evidence from a study of girls and young women who are in schools and colleges in the north and south of England. As part of Generation 9/11, the girls have been educated most or all of their lives in the shadow of the war on terror and also are the first generation to be considering their future options in the immediate aftermath of the Brexit referendum. The first section gives some background information on the changing picture of educational attainment for Muslim girls in the context of recent policies that promote social mobility. The second section explores theories of choice and aspiration in order to locate the paper within current debates about how Muslim women navigate resource of constraint and possibility. I then discuss the findings from the

\footnotetext{
${ }^{1}$ The prevent duty which came into force in 2015 places a stator requirement on schools, colleges and a number of other public bodies including NHS trusts ad prisons to report concerns about people who may be at risk of during to extremism or terrorism.

2 The government defines these as democracy, the rule of law, individual liberty, and mutual respect and tolerance of those with different faiths. Since 2014, teachers in English schools must promote these British values and their promotion is inspected by Ofsted.
} 
empirical research; this was conducted over a two-year period with Muslim young women who are currently navigating education and considering their options for the future in the north and south of England. The analysis presented reveals some contradictions at the heart of the education system in that while girls are being encouraged to aim high, be aspirational and successful, they are also tasked with accepting responsibility for the structural and racialised disadvantage that prevents many Muslim women from translating educational success into labour market advantage.

\section{Background and context}

In the last decade, social mobility has been high on the political agenda (Payne, 2017). However, the evidence referred to above from the Social Mobility Commission $(2016 ; 2017)$ in regard to young Muslims, questions the effectiveness of recent policies. For sociologists this is unsurprising since they have argued that relative inequalities (the differences between the most and least advantaged) have not changed in the last 60 years and the gap between the rich and poor has even increased (Goldthorpe, 2016; Payne, 2017). Sociologists also point out that social mobility, as re-conceptualised in the UK under successive governments since the early 2000s, reflects a problematic individualism. Rather than helping the poorest children, the strategies pursued have focused on encouraging disadvantaged children to be more competitive (Reay, 2013; Maslen, 2019) in order to fight for what is arguably declining 'room at the top'. The problem with this individualistic approach is that it diverts attention from the structural inequalities that shape the lives of poorer communities. The model of social mobility that is currently being promoted, assumes that opportunities are there for the taking as long as people are prepared to work hard (DfE, 2017). The onus is therefore placed on individuals to engage in self-improvement or betterment as a way to make themselves more employable and to climb the ladder. Rather than 'expecting' the state to create or provide employment opportunities, individuals are encouraged to be more aspiring (Gewirtz 2001; Raco 2009).

Patterns of educational achievement for Muslim students 
While policy makers continue to champion social mobility as the solution to growing inequalities, research on educational outcomes (Mirza 1992; Gillborn and Mirza 1998; Gillborn and Youdell 2000) has shown that class and ethnicity (not individual merit) remain the biggest predictors of educational success and failure. Gillborn $(2008,59-60)$ maintains however, that statistics on ethnicity and achievement confirm a complex picture with girls performing better than boys across the board. Since 1992, the achievements of Pakistani and Bangladeshi young people (described through categories of South Asian and now Muslim) have varied considerably, showing that existing inequalities are not fixed. All groups have enjoyed some improvement over the period but the Black-White gap has remained fairly constant. While lower socioeconomic status Pakistani and Bangladeshi groups increased attainment in recent years (DfE, 2019) both Bangladeshi and Pakistani students have also experienced periods of growing inequality in the last two decades (Gillborn 2008, 60; Ali, 2015). There are few detailed trends for other Muslim minorities, but research on Turkish youth by Enneli, Modood and Bradley (2005) and by the Department for Communities and Local Government (DCLG 2009) indicate that Turkish Cypriots perform better academically than students from mainland Turkey, whose educational performance is similar to that of Pakistanis and Bangladeshi. Khattab and Modood (2018) argue Muslim students make progress at the later stages relative to those with the same scores at an earlier level and that Muslim girls seem to now be outperforming Muslim boys in relation to their school performance. (Khattab and Modood 2018).

The picture of Muslim attainment is further complicated by the research evidence on educational choices, particularly in the context of university application (Modood and Shiner 1994; Modood and Acland 1998; Ahmad 2001; Ball, Reay and David 2002; Reay, David and Ball 2001; Abbas, 2004: Modood 2006; Shah, Dwyer and Modood 2010; Housee 2018) This body of research suggests that Muslim Pakistani and Bangladeshi students, often the poorest and most marginalised of English students, are nonetheless more likely than White workingclass young people to submit applications to university. This is increasingly the case for Muslim women whose participation in education is becoming routine (Ahmad, 2001; Bagguley and Hussain, 2016). 
Much of the earlier research on higher education decision-making (Reay, David and Ball 2001; Mirza 2009) pointed to a 'troubling racial divide' in students choices, between 'old' (pre-1992 established universities) and 'new' universities or those former polytechnics accorded university status following the 1992 Further and Higher Education Act. Modood (2006) argues that ethnic minorities are less likely to enter the more prestigious 'old' universities and are more likely to withdraw from university. Those who last the course are less likely to gain a high-grade degree. Modood also argues that all these factors apply less to Indian and Chinese students than other groups. Ethnic minority students are more likely to be part-time or mature students-which often means that they are less likely to obtain more prestigious and better-paid jobs (see also Bhattacharyya, Ison and Blair 2003). They are also more likely to feature disproportionately in medicine, and health-related subjects, law and business, engineering and ICT but are underrepresented in the pure sciences and the humanities; as Modood (2006) argues, only a few universities and not all disciplines can truly claim to be multi-ethnic.

Due to changing demographics, Muslims are now the fastest growing younger population of all ethnic groups born in the UK today (Ali,2015). With steady rises in the numbers of ethnic and religious minority students accessing in higher education in the last decade (UUK, 2019) it might also be expected that newer generations will break through some of the barriers to success that were faced by earlier generations of Muslims. However, as the Social Mobility Commission has found, increased participation in higher education is not necessarily translating into labour market success for Muslim students; existing classed, gendered and racialised inequalities are therefore being reproduced. The next section explores some of the theoretical work that has addressed these issues.

\section{Theorising educational aspirations and the reproduction of classed, racialized and gendered inequalities}

Within the educational literature, arguments linking educational choice and the reproduction of classed, gendered and racialised inequalities are now well-established (Ball, Reay and David 2002; Reay, David and Ball 2001; Ball 2003; Archer and Yamashita 2003; Archer and Francis 
2006; Crozier and Davis 2006). Much of this educational literature has been underpinned by the theoretical tools offered by Bourdieu, most notably his concepts of social and cultural capital. Research on transitions to higher education has consistently shown that choices are shaped by the availability of resources (material and cultural), which can enhance or constrain aspiration, achievement and ambition (Wright, Standen and Patel 2010), leading to the reproduction of existing classed, gendered and racialised inequalities. Ball (2003), for example, argues that the White middle classes are 'adept at taking up and making the most of opportunities of advantage that [marketised] policies present to them' (261). These White middle-class families have the capacity to maintain competitive advantage due to their possession of embodied forms of social capital (the links and networks that support what might be possible or what can be done) and cultural capital (the possession of understandings, knowledge, ways of behaving and attitudes which can either help or impede a person to progress) (Hodkinson 2004). Although research on working class students shows that a complex array of factors impacts on their aspirations and choices, many working class students, regardless of academic ability, tend to define traditional universities as simply out of their reach. They either lack the resources required or possess the 'wrong' sort of capital for success in elite higher education institutions (Reay, David and Ball 2001).

Whereas this 'social reproduction' literature has addressed intersections of class, race and gender in the reproduction of inequalities, its underlying Bourdieuian framework has been criticised as overly class-based and unable to 'explain educational success among individuals who lack class-related resources for mobility (both economic and cultural capital)' (Thapar and Sanghera 2010, 9).

Researchers studying the unexpected success, relative to their peers, of British working class Chinese and South Asian students, have drawn instead on notions of 'family capital' (Archer and Francis 2006, 7) or 'ethnic capital' (Modood 2006). For Modood this refers to the crossclass value that British Pakistani parents place on higher education and high career aspirations for their children. Extending this notion, Shah et al (2010) argue that the transmission of values and aspirations related to education within and between families and the enforcement of norms and sanctions are important in explaining why many working-class Pakistani students access higher education. However, differences in the outcomes for siblings 
within the same family unit point to the need for a distinction to be made between potential and actualised ethnic capital. They argue that gender (hierarchies, ideologies and identities) and religion (identities and practices) matter but so do structural disadvantages in terms of influencing the level of ethnic capital that is actualized. This explains variations in achievement and aspirations within working-class British Pakistani families. Shah et al, argue that assessment of the potential of ethnic capital in achieving social mobility needs to be contextualised wider debates about the social locations of individuals and groups.

Bagguley and Hussain (2016) challenge what they describe as the ahistorical basis of theories emphasising ethnic capital. If ethnic capital is something that is possessed by South Asian migrant parents, then what accounts for the low higher education participation of South Asian women 20 years ago? They focus instead on the processes of decision-making about higher education which they are argue are overlooked in theories of social capital. 'Choices' also involve negotiation and sometimes conflict over complex interrelated issues and motivations for South Asian women, including subject choice, location and when to get married (Ahmad, 2001; Dale et al., 2002; Hussain and Bagguley, 2007).

Bagguley and Hussain maintain that social capital approaches risk treating young people as 'empty vessels' who lack agency and their own strategies. Drawing on the concept of 'metareflexivity' they argue that young women are challenging parental and community pressure and expectations about which subjects to study. Their desire for occupational mobility for themselves, their children and their communities is linked to collective ethnic identifications. The concept of meta-reflexivity enables them to focus on how collective ethnic identifications are enacted and/or resisted and transformed.

Khattab and Modood (2018) agree with Bagguley and Hussain in pointing to the individual agency of Muslim women in driving forward their higher participations and achievement. They see Muslim women's own unusually high expectations of going to university as critical here. However, they argue that these high expectations have most likely been shaped in turn by the expectations of parents though 'the messages the children receive, the discipline in place in relation to school work at home and the girls' relationship with their parents and their parents' norms'. 
The theories referred to above put forward a range of explanations of how Muslim women's aspirations and future expectations might be theorised, in particular, how they might develop 'getting on' strategies. I also find useful, Yosso's critique of Bourdieuian cultural capital theory which she argues tend to privilege White middle-class standards as the norm against which other forms and expressions of culture are judged as culturally wealthy and culturally poor Yosso $(2005,76)$. From a Critical Race Theory (CRT) perspective, she argues that the working class in general and racialised minorities, in particular, are assumed to 'lack' cultural capital rather than possessing other valued forms of capital. Yosso introduces the alternative concept of 'community cultural wealth' to refer to 'an array of knowledge, skills, abilities and contacts possessed and utilized by racialised communities to resist the impact of macro and micro forms of oppression' $(2005,77)$. Among the six forms of capital that are central to community cultural wealth, Yosso includes aspirational and resistant capital. Aspirational capital is defined as 'the ability to maintain hopes and dreams for the future, even in the face of real and perceived barriers' (77).

Yosso argues that this form of capital promotes resilience and a 'culture of possibility' (78) in the face of a multitude of structural inequalities and racial hostility. It is the supportive networks, primarily the extended family and neighbourhood/kin, which carry a sense of community (79). This in turn provides individuals with the resources needed to deal with the impact of structural oppression.

Yosso's argument therefore emphasises the continued significance of community cultural networks in supporting young people's aspirations and decision making. Her notion of 'resistant capital' refers to 'those knowledges and skills fostered through oppositional behaviour that challenges inequality' $(2005,80)$. Whereas Yosso refers to the US context, researchers in the UK (Sivanandan 1982; Gilroy 1987; Mirza and Reay 2000) have also documented collectivised struggles and strategies that emerged directly as a response to the structural racism experienced by Black parents in the 1960s and 1970s. Campaigns against racism and other 'social movements' such as the setting up of Black supplementary schools (Mirza and Reay 2000) could be argued to demonstrate the significance and operation of both aspirational and resistant capital. 
It is against the background of these policy and theoretical debates that the current paper explores the Muslim girls' talk about their aspirations in relation to education and employment and family life. My aim is to identify the resources (ethnicity, family, gender or individualised) that the girls draw on in relation to their current educational choices and imagined futures and, specifically, to explore how they navigate the unequal education space in post-9/11 Britain.

\section{Research methods}

The paper draws on qualitative research that set out to gather British Muslim girls' narrative accounts of growing up and being educated in the shadow of the war on terror. Data was collected between September 2017 and May 2019 and consisted of 19 in-depth interviews conducted with girls aged 13-19 in school and further education and 4 young women in their early 20s, who were currently in higher education. In addition to the interviews, focus groups were conducted with girls aged 13-16 in secondary schools involving a total of 77 young women.

The girls who took part in the research identified as either practising Muslims or as being of 'Muslim descent' (Ahmad, 2001), or 'culturally Muslim' - they had family connections to Islam but were not necessarily practising themselves. The sample consisted of young women from a range of Muslim ethnic backgrounds. This included the more established Muslim minorities (eg Pakistani, Bangladeshi) and newer migrant Muslim populations (Afghani, Turkish, Somali, Moroccan, Lebanese).

The main fieldwork was carried out across two geographical areas: a northern town and a southern city. In each location, focus groups were conducted in two mixed secondary schools. Interview participants were recruited via a poster call with the support of schools and colleges in both geographical locations. The poster was also shared via social media and attracted two young women who were undertaking further education in the West Midlands. 
Of the 23 girls and young women who took part in the interviews , 10 described their ethnicity as Pakistani; 5 as Bengali; 3 as Somali; 1 as Moroccan; 1 as Turkish; 1 as Arab and Somali; 1 as Lebanese and English; 1 as Turkish; 1 as Turkish and Pakistani. The majority of participants across the interviews and focus groups were UK-born. Four of the interviewees could be described as middle class, based on their parents' occupations (Raheela's father was a professional musician, Nadia's parents were both academics, Samina's father was an academic and Malika's parents were medical professionals); The occupational status of other parents ranged from care-work to teacher-support, taxi-driving to not working at the time of the research. This pattern was reflected in the focus groups and so the sample was predominantly working class.

The research received ethical approval from my university and was conducted in line with the British Educational Research Association's guidance on ethical research practice. Full and extensive written information about the project was issued at least three weeks ahead of any proposed meeting dates so that informed consent could be established. Consent was reconfirmed before and after the interviews and focus group meetings with participants and institutions being given further opportunities to withdraw all or part of their data up to three months after the date of each interview or focus group. This was particularly important given the sensitivity and political nature of some of the information that was shared. Pseudonyms have been used throughout this paper to protect both participant and institutional identities.

In terms of the analysis, each interview was read to identify a dominant narrative thread and key themes; the focus groups were analysed thematically. Key themes were then identified across the two data sets to arrive the final themes that inform this paper. The next section presents the data in relation five themes: Educational and career ambitions; Choice of university; Sources of support; Independence and 'driving oneself'; Navigating gendered racism.

\section{Findings and analysis}




\section{Educational and career ambitions}

The majority of the young women across both the interviews and focus groups articulated very clear future plans, almost all of which involved studying beyond compulsory education. This falls in line with the findings of recent research on Muslim girls' post-16 aspirations (Ahmad 2001; Abbas 2004; Shah, Dwyer and Modood 2011, Crozier and Davies 2007; Bagguley and Hussain, 2014 Stephenson et al, 2017; Khattab and Modood, 2018) and the evidence of the rising participation rates of Muslim women in higher education (Woodward, 2018). Forensics, medicine, law, dentistry and health and social care were among the commonly cited career choices. Researchers have argued that the preference for subjects such as law, medicine and business can lead to an over-representation of minority students on such degree courses and increased competition for jobs and higher education places in these fields (Hussain and Bagguley 2007; Tackey, Barnes and Khambhaita 2011). However, within the current research the young women also expressed preferences for 'less traditional' options which included social science or creative/arts-based degrees and jobs. For example, Raheela aspired to be a pilot and was looking for an apprenticeship. Aisha, sought a career in performance and publishing and while her parents wanted her to study sciences she had compromised by applying for a degree in social anthropology. Similar negotiation and compromise was involved in Malika's case. She had chosen to study politics and explains below that her parents, both medical professionals, wanted her to follow in their footsteps. However, they were nonetheless supportive of her choice.

[My Mum] was like well, we're not going to pressure you to be doctors and stuff but think about being a dentist, they earn so much money. I was like, I can't do chemistry, I will fail, so please don't make me do this. So, after that at A Level, I chose politics, sociology and economics. And then, that's where I found out I really liked politics. And .. I was like I want to do politics at university, please let me. And my mum was fine with it. (Malika, HE, South)

Malika's response highlights the closeness of family and continuing tradition but also aspects of change though cultural navigation in the context of the changing structural arrangements within higher education (Bagguley and Hussain, 2016). Only two of the young women, 
Shereen and Haleema, showed 'uncertain' aspirations. However, as their accounts below illustrate, they too expressed preferences for further study and work over marriage.

I'd love to continue learning and after that, l'd love to have a job or maybe some time in the future get married. I'm not quite fussed about that yet. It's more about learning and getting a good job first. (Shereen, FE, North)

[I'd like to go university], but I don't know what I want to do at University yet. I would want to say local so that so that I don't have to leave my family all the time. (Haleema, FE, North)

\section{Choice of university}

Much of the earlier research on the higher degree choices of Muslim students noted a preference or a 'settling for' new (post-1992) universities. Based largely on the negative experiences of older siblings and friends, disadvantaged students did not expect to gain entry into Russell Group universities and so applied to their nearest university (Shiner, Noden, Modood, 2014; Boliver, 2013). This was not the case for the majority of the girls in this research whose plans overwhelmingly involved studying at either pre-1992 or Russell Group universities. These plans were informed in many cases by the success of older siblings in gaining places at these more prestigious institutions. There was however, a seeming north/south divide in university choice; while the 'northern girls' opted for the closest Russell Group university based on it being a commutable distance and/or a sibling having attended there, 'southern girls' largely expressed more 'course-driven' choices and were more willing to live away from home:

\section{IV: So why Manchester [for Medicine]?}

Aminah: It's closest. I just really don't think I will be able to move out because I don't think I'm that independent yet. I rely on my parents for everything, and my siblings, so, I thought, it's closest and it's a good university.

(Aminah, School, North) 
I've narrowed it down to the following, and I was willing to travel as far as Edinburgh

- though of course, the law would be a different specialism there. So, I have chosen LSE, Warwick and York (Farah, FE, South)

While Farah received support from her family to study away from home, Themina explained how the decision to move away had to be negotiated:

Themina Well, I've applied to uni to do English with creative writing. And I have an offer from Royal Holloway University which is one I really want to go to.

IV Amazing. And was that your first choice?

Themina Well, I applied for Cambridge, I got an interview but I got rejected. But I wasn't that upset. Royal Holloway was my first choice... after Cambridge and when I didn't get in I was really happy because I have an unconditional offer so I'm definitely going uni.

IV And how are your parents feeling about it?

Themina They don't want me to leave, but I have to go so. My dad's still trying to convince me you can stay in London. (Themina, FE, South)

Like Themina, Rasheeda also talked about the need for negotiation with her family regarding her choice to study medicine at her local Russell group University.

I would love to do the Uni accommodation stuff. I have had a couple of chats with my mum. She is not too pleased about it. ..She is thinking..you are at home, you have got no responsibilities, you are not paying the rent. Why do you want to go live out there? I will learn to live independently, won't I? .. I would prefer to do things for myself. In the morning instead of just getting dropped off, I prefer to get the train by myself. ... Living away from home would definitely be hard, but I would love to do it. Definitely. (Rasheeda, School, North) 
Again, in line with the recent literature, the young women reported receiving considerable support for their post-16 aspirations from their families with mothers being identified as key role-models (Shah et al, 2010; Crozier and Davies, 2006, Mirza and Meetoo, 2018):

My mum ... because she's been through a lot of hardship in her life. And she's ... the most selfless person that l've ever met and she never puts herself before anyone else. And I just find that so admirable, .. She really encourages me. (Themina, FE, South)

Probably my parents, because they just support me in whatever I do and they're always trying to motivate me. So I just really wanted to do something and just make them proud. (Aminah, School, North) .

These findings question the dominant representations of Muslim and south Asian women within British policy discourse where they are too often negated as having low aspirations, poor language skills and lacking agency. These factors were constructed as obstacles to the success of ethnic minority women within the Government Green Paper on Integration (HM Government, 2018). The emphasis on culture as a block to success is also challenged within the Women's Budget Group's report (2017), which concludes that the key barriers to the economic success of minority women are structural: these centre on ethnic minority women's generally poorer status within society and the discrimination they face as minoritised women (Farris, 2018).

Alongside parents, sources of advice about where to study included older siblings and relatives. This was particularly significant in the case of girls whose older sisters were the first in their families to go to university or live away during their studies and who were seen as role models or pioneers. This finding corresponds with previous research (Bagguley and Hussain, 2007; Shah et al, 2010; Crozier and Davies, 2007, Stephenson et al, 2017). In some cases, relatives and family members used themselves as 'negative examples' (Shah et al, 2010) to encourage the girls to stay on in education. These relations could be seen to 
represent the collective and community spirit that Yosso (2005) refers to a 'aspirational capital' - the supportive networks within extended family and neighbourhood/kin, that carry a sense of community (79), which in turn provides individuals with the resources needed to deal with the impact of structural oppression. Family members were actively supporting the girls, through sharing their stories, to seek ways of improving their future prospects.

My brother. Definitely. He is the one I am closest to. He has always been there for me. If you need anything, he says, just tell me. He literally would do anything for me if I asked him to. He has worked his way up a lot, he has had a lot of hardships. (Rasheeda, School, North)

[T]hey (cousins) are always saying, oh do you ever want to talk about what you want to do in the future or any career that you want to talk about? And they always advising me which university or which college I'd ever want to go to. (Malika, School, North)

The support that Rasheeda and Malika refer to in the form of advice and 'sharing experiences' offered by close relatives and family members can be seen to represent a form of bonding capital (within class or community connections). However, as Farah's account presented below highlights, this advice and sharing did not translate into the kind of bridging capital (connections and contacts that go beyond the immediate community group or class) that is often needed to gain competitive advantage in the current education market.

Farrah I mean, .. there are, firstly, opportunities that you don't hear about because of, like, the school you go to. Like, I remember a friend of mine, I was Facetiming them, and their mum sort of walked in and just went, hey, [London University] has summer schools. It's called [xxx], you should definitely apply to it. And I remember thinking, my mother's never going to know about these things. Like, I'm never going to be told by my mum to apply for [London University] summer school. But it's not that that person's got a better chance of getting into their summer school than me. I just have to look on their website and I would find it myself. And I just think, a lot of the time, there's a lot of free stuff you can sign up 
for and apply for. But then a lot of the times you've got these opportunities like Duke of Edinburgh, like exclusive sports that you need a lot of money to do.

... You don't have to do them and you could definitely do something that you can gain the same skills from, but...

IE: $\quad$ So you've just like Googled things and you found things for yourself.

Farrah: $\quad$ Yes, And I think when I speak about these or when I've then gotten them, I can say, this is on my merit alone, not because I've got connections. And when I then speak about them on a personal statement or in an interview, I have a story to tell of how I got them. And it isn't, I asked Mummy to get it for me. So I don't think it puts me at a disadvantage.

Farah highlights the lack of access to the sorts of networks, contacts and resources that could potentially support her to make the transition from school to higher education. Her account appears to be contradictory in that she seems to both reject, and accept, the discourse of meritocracy. She simultaneously demonstrates awareness of, and expresses frustration about, the competitive advantage that middle class people are able to accrue due to their cultural and social capital. Farah articulates her own strategy which involves a solid determination to find out these things for herself. Seemingly internalising neoliberal notions of self-improvement, her account can also be read to demonstrate 'resistance capital' (Yosso, 2005) in that Farah's determination to succeed can be seen to be is borne out of the disadvantages she knowingly experiences. Whatever theoretical interpretation one accepts, Farah's account illustrates a strategy of self-reliance which was a common feature of the young women's responses. While being encouraged to be aspirational by their schools, the girls' accounts revealed that the schools were not necessarily equipping them with the tools that were needed to gain the competitive advantage required to succeed in the current system. Instead, as the next section reveals, the girls were internalising these messages of self-reliance and self-improvement.

\section{Independence and 'driving oneself'}

The girls' accounts were littered with references to 'working hard', 'being independent', being 'driven' and wanting success. This finding cut across class background, ethnicity and 
geographical location. All of the girls mentioned that they wanted a career, rather than work and career before marriage.

I feel like if I speak it into existence it should happen. And I put in the work, it should happen. Yes, success. ..... I'm very worrisome, I'm constantly worried about every thing. I feel like I'm constantly looking over my shoulder. (Aisha, FE, South)

Work as hard as you can, because then you'll get to the top. If, you're at the bottom from the start, then you're not going to get far ... People are not going to expect much from you But if you are working hard, they know that you have the capability to do something and then you'll get support from everybody. (Raheela, School, North)

Aisha's and Raheela's accounts highlight how the task of responding to changing labour market conditions is internalised by young people, with success and failure framed as an individual enterprise. In Yossos' (2005) terms this could be read as a determination to succeed in the face of hostility. The girls had internalised the need to work twice as hard as their white counterparts in order to get the support that was needed. It was also quite striking how many of the girls prioritised the need to learn to drive:

What I look forward to the most is driving'. I'm looking forward to having kids as well but I want to have a career and to be able to drive. (Malika, School, North)

Having stability. Having a job with a steady income where I can look after myself, and I'm not dependent on anyone. (Farah, FE, South)

As soon as I can drive, I will be driving. That is my hope. It's just having your own freedom and going where you want. As in right now you have to ask someone to take you somewhere or get in a taxi or get a bus. (Shereen, School, North)

The girls cited above, like those in the wider sample, placed a high value on careers ahead of settling down with a family. This contrasts with research on earlier generations of Muslim and South Asian girls (Basit 1997; Dwyer, 1999, Shain , 2003) which reported more varied 
responses. In these older studies, some girls expressed preferences for marriage over future study. Girls such as Fauzia (School, North), did talk about looking forward to having families but their narratives were also full of talk about being independent and having a career. Selina's narrative is another case in point:

I don't what a job. I want a career ... It's definitely going to be something to do with the social worker scene. [What I look forward to most] is being independent fully, so like being my own person. So I wake up and I'm in my own house and I drive myself to work and do my own work and then come home, make my own tea. (Selina, FE. Midlands)

The above accounts reflect post-feminist and neoliberal rhetoric of the entrepreneurial, hardworking self. However, when read through the lens of the racism that filters the experiences of Muslim and black and minority women, it can also be argued that the desire to drive might reflect a strategy of self-protection in the context of rising anti-Muslim hate in a post-9/11 context. This is revisited later in the paper.

Only two of the interviewees talked openly about the socio-economic disadvantage they faced or expect to face. Aminah, referred to earlier, was planning to study social anthropology. She referred several times within her interview to 'being broke' ('I'm broke, I've been broke all my life') and needing to make money. While she aspired to go to university and was expecting to get the grades, she also talked about the possibility of a gap year due to financial constraints. Aminah did not, however, explicitly connect 'being broke' to structural factors such as being part of a poorer community. Farah on the other hand, made explicit connections between being working class and wider structural factors. In the account presented below she refers to the way in which the current education system is designed to prioritise educational competition above the individual needs of its students.

Farah [W]hen I applied to sixth form, I applied with all A stars and I actually went in with six A stars. And .. one of our partner schools is [well-known prestigious private school]. And so I have a buddy from [private school]. And I remember talking to him about it, and I remember him saying he got ten A stars. And I was like, I could 
have gotten that. And back then, when I came to GCSEs, I really didn't care, because I was like, the sixth form I go to, they required five A's. So my objective at that point was just to get five As. ... But then when I got to sixth form and I started looking at unis, I really, really regret not putting in, like... . significant more amount of work. I just needed to put in a little bit of work to get... And it was really annoying because when I got my results back, with three of my subjects I was... With history I was one mark off an A star. With biology I was three marks off, and with business I was four marks off. And .. this is how I knew I was definitely not going to stay in that school.... I asked them, do you reckon if I got them re-marked I'd get them changed to an A star? So I asked my school if they could do it for me, which most schools do, and my school was like, we only do it if you've got a $D$ and if you're a few marks off a $C$, because they want to get the pass rates. And like, you've already got an amazing grade, and, like, it's an A. Like, that just said everything to me, that they didn't care about you as a student and you getting the A stars that you want. They cared about you as a statistic and you contributing to their pass rate. And I already passed, so I wasn't contributing any more to their pass rate. .... I'd already contributed to it.

I quote at length from Farah's account because it highlights some of the contradictions at the heart of the current English education system. Farah, talked in her interview about how she had been encouraged by her school to embody success. The school she attended was a high performing state school and students were constantly reminded about how fortunate they were to be attending there (Bradford and Hey, 2007). However, Farah's account reflects a sense of feeling instrumentalised. While the encouragement from the school to be aspirational was positive, Farah felt that it was school's reputation and its position in the league tables that was driving them to push girls like her to be successful. Farah's account resonates here with the findings of feminist research that has explored how girls' potential for educational success can be instrumentalised as part of the neoliberal international development agenda. The Nike Foundation's global Girl Effect campaign, championed by major NGOs is a case in point (Shain , 2013; Rasheed, 2015). Farah's account also connects with research which has found low teacher expectations with black and minority ethnic girls 
being told that they should be satisfied with what they have achieved to date (Rollock, Vincent and Gillborn; Mirza and Meetoo, 2018).

As stated, Farah was one of the few girls to talk openly acknowledge the issues of socioeconomic disadvantage. However, as the next section covers, it was a different story in relation to gendered racism.

\section{Navigating gendered racism}

All the girls, regardless of class background, ethnicity and geographical location spoke about the rising tide of nationalism and racism in the post-9/11 and post-Brexit referendum result era. They reported either witnessing or directly experiencing gendered racist abuse. The research was conducted in the immediate aftermath of the Brexit referendum vote in 2016, in which Britain voted by a slim margin to leave the Europe Union. While it is difficult to make direct links between Brexit and the racial microaggressions and anti-Muslim hate that the girls reportedly experienced, some notable spikes in anti-Muslim hate crimes were recorded in following the referendum result (Tell MAMA, 2018).

Aisha: People [say that] people are so much more racist now post-Brexit, and I'm thinking I've been racially attacked before Brexit. People are a bit misinformed. Outspoken racist white people... Racist white people exist everywhere, they're just more covert about it. I guess obviously disenfranchised ones, the poorer more, far right wing people are just more loud about it sometimes.

IV: $\quad$ So when you say you've been racially attacked?

Aisha I mean, have you ever been on the tube and there's a drunk white person and they're just shouting at you and insulting you?

IV: When was it that this happened?

Aisha: 2016-ish. I think it was just before Brexit. But then at the same time I guess it would fall under post-Brexit 
Aisha notes here that although the incident took place prior to the referendum date, it was most likely connected to populist rhetoric that was in fervour in the run up to the Brexit vote. There were many accounts from other the young women about being abused while using public transport which may in some way explain the desire of the young women to learn to drive. Nearly all of girls reported incidents, that they or others within their local neighbourhoods had been witness to, ranging from racist graffiti and vandalism to verbal abuse and assault.

Nafisa: My Mum was ....waiting at the bus stop and, like, she felt people throwing, like she could feel stones on her. And she still just had to walk away from it.

Shamsad: It happened in Birmingham mostly, the incidents, yes. Muslim girls who were wearing hijabs, they got acid thrown on their face and scarves taken off.

Nabila: My cousin, she is pregnant, and they live in [northern town]. It was around then, she is nine months and she got chased by a van. They wanted to run her over, but she got away.

(Focus Group, school, North)

The girls also spoke at length about their various reactions to the hate fuelled flyers sent to Muslim families declaring April $3^{\text {rd }}$ as 'Punish a Muslim Day'. The flyers, sent in March 2018, advocated 'points' for violence against Muslims, with 10 points being awarded for verbal abuse to 80 points of throwing acid in a Muslim's face and so on. While the day passed with little incident, some of the girls admitted that the incident had impacted significantly on them/ their families:

Noor: It was quite frightening, my parents didn't let me out of the house' .

Ferhana: Normally I just walk everywhere but that day, my dad insisted on giving me a lift.

(Focus Group, School, North) 
However, it was notable across the accounts how little this issue had been addressed within school space. Across the interviews the young women spoke to a greater or lesser degree about being well-supported by individual teachers within their respective schools. However, they reported gaps and silences within schools and colleges following the occurrence of racist of terrorist incident. On the rare occasion that terrorism was discussed in assemblies or meetings, the girls reported they felt responsiblised in the process -the onus was on them to 'prove' that they did not support Islamist extremism. As Zeenat explains:

[W] hen the teachers talk to us about terrorism, they're not really saying it to the nonMuslim kids, you know what I mean? They're trying to make it out as if it's towards everyone but it's not. ... when you've grown up knowing how to behave and act and you have put all this effort into your studies and education, for someone to then tell you, stop, you need to chill out, don't be a terrorist. It's just like ..I am trying my best to prove to everyone else, who's not Muslim, that that's not what I am like. That's what it feels like nowadays. Like you have to work hard just to prove that you are not a terrorist. Or you have to be extremely, extremely nice, even with people who are being rude to you, just to prove that. Because as soon as you show a bit of anger, they'd be like oh, ISIS or terrorism, you know. (Zeenat, School, North)

None of the girls had considered reporting or discussing such incidents within school space. This was partly due to a sense of the curriculum being crowded and partly because the girls had a sense that teachers were not fully prepared or equipped to offer support with such incidents. As Rasheeda explains, the message internalised by the girls as a result of the gaps and silences in education, was that they just needed to get on with it.

IV Who helps you get through all of this? Who do you turn to?

Rasheeda To be honest, we have learned to deal with it independently. Sometimes we are so used to it, we don't even see it, hardly. If it is happening, we just learn to live with it. You can't really do anything about it, can you? ....You find other ways out of it don't you? 
However, some of the girls were actively considering their post-16 futures away from the UK. The Trump travel ban and the Brexit situation, alongside the constant need to prove they were not extremist were factors in the process:

I know that I will not be able travel to the USA so I have made the decision to live and work in the East. (Hafsa, focus group, North)

I'm looking for jobs in China - that's where I see my future. (Rasheeda, FE, South)

Gazalla: I want to go into law and take up a career as a barrister but maybe focusing on Asia, like Hong Kong, Singapore, more like the business side of it all because I feel like with the current situation going on...

IV: $\quad$ When you say current situation, what...

Gazalla: Like trade wars and China and Donald Trump, stuff like that. The economy is changing especially after Brexit's going to happen in, what, two or three days. I don't really want to be here for it. I'd rather try and get out of here as quickly as possible..I am so upset about Brexit. I really feel like it's ruined it for us....[t]here's a lot more racism that sprung upon it because most people only voted so they could keep people out of England. They didn't actually know the repercussions of it. Also, for me, it worried me a lot because that's my future just done like that. I'm not going to have opportunities that others have had previously and I've been working hard since I was 11 years old. So, for some people to just make that decision for me, it's really stressful. That's why it's made me get this ambition of moving abroad and working there because I don't think I can stand to work in here. (FE, North)

Like many of the girls, Gazalla talked openly in her interview about the impact that that the current political stigmatising and cultural 'otherling' was having on her mental health. 
Gazalla: I think it's just like all these current terrorist attacks, they happened... so many over a short period of time that it was easy for other people to label me and other girls as well because they made us out to be the enemies and stuff. It's just something that you don't really want. Especially like I said before, growing up .. growing up with all the white friends, it's just like, oh my gosh, I'm not used to this.

As a Generation 9/11 young woman, Gazalla had grown up with the pressure of constantly having to be guarded and to prove that she was not 'extremist'. Indeed, Gazalla considered herself to be a 'well-integrated' British person. However, the fall out after a recent spate of terrorist incidents following hot on the heel so the Brexit referendum had left her feeling disillusioned. Gazalla, like many of the young women in the research, expressed frustration at being made to feel responsible for terrorism and the social problems connected to austerity. Her personal strategy was to plan to leave the UK altogether.

\section{Conclusions}

This paper has argued the Generation 9/11 British Muslim girls are growing up in an era where individuals are being expected to carry the burden of risk and responsibility for the changing conditions and availability of work. They are encouraged to work hard and to be aspirational, but the government's own statistics (Social Mobility Commission, 2016; 2017) indicate that that they may be unable to succeed within the labour market because the odds are stacked against them. The structural factors include a transformed labour market, where entry level jobs are harder to get, higher qualifications are demanded and under-employment and insecure jobs are now the norm. The competition for higher education places has also been fierce but in the context of changing demographics, with Muslims comprising one of the fastest growing younger populations (ONS, 2011), there are also opportunities available to this generation of young women.

As the analysis offered in this paper reveals, traditional structures and intersections of class, gender, ethnicity and neighbourhood remain highly significant in Muslim young women's construction of current and future choices and life trajectories. However, the research also 
revealed that decisions were made on the basis of negotiation and that some of the traditional choices were giving way to newer and more varied options and expectations. While they did not talk openly about the potential socio-economic discrimination, the girls' accounts also reflect the language of individualisation that is currently embedded in neoliberal education policies and the government's advisory work on social mobility. As the analysis shows, 'being independent', and 'working hard' were frequently referenced by the girls in talking about their imagined and expected futures.

A range of factors account for the educational aspirations of Generation 9/11 Muslim girls. Some of this can be explained through notions of 'ethnic capital' (Shah et al, 2010)- the high expectation of higher education participation and attainment that is shared by ethnic minority parents and their children. While the girls were aiming for traditional subjects in prestigious universities, there were also negotiating support for 'less traditional' degree subjects within the arts and social sciences. However, there was also evidence of resistance capital (Yosso, 2005) where the girls seemed to be working twice as hard because they knew the odds stacked against them.

The girls were carefully negotiating their futures in the context of changed opportunities and risks. In doing so they drew on support from various sources within their communities and beyond. This also to some extent reflects Yossi's notion of aspirational capital, a determination to succeed in the face increased hostility - they were crafting a culture of possibility. It was not just blind aspiration - but resilience because their post 16 futures and indeed their present is being shaped by the war on terror and the fall out for the Brexit referendum.

The accounts presented in this paper also show that young Muslim women are doing all the 'right things' in education - they work hard, have high aspirations and aim high. Compared with earlier generations they have their sights set on a wider range of degree courses at more prestigious institutions. Yet, while being encouraged to be successful within schools, they are also left to their own devices to find ways of coping once they have achieved the requisite 95 GCSE results or A* results for their schools. The individual needs of the young women are often marginalised at the expense of the schools' need to compete within the education 
market. With reduced funding for state schools and increased expectations that they will deliver 'higher standards', this leaves notable gaps when it comes to supporting disadvantaged students beyond 'getting the grades'. Particular gaps have been highlighted in relation to the support offered to the young women in the hostile environment that has resulted following the 2016 Brexit referendum and the ongoing impact of 9/11 on the education of Muslim girls. While regularly subjected to surveillance and monitoring for signs of extremism, British Muslim women are offered little protection from the rising levels of extremism that target them because they are Muslims.

\section{Acknowledgements}

[removed for review process]

\section{References}

Ahmad, F. (2001). Modern traditions? British Muslim women and academic achievement. Gender and Education, 13(2), 137-152.

Ali, S. (2015). British Muslims in numbers: A demographic, socio-economic and health profile of Muslims in Britain drawing on the 2011 Census. Muslim Council of Britain, London

Archer, L., \& Francis, B. (2006). Challenging classes? Exploring the role of social class within the identities and achievement of British Chinese pupils. Sociology, 40(1), 29-49.

Archer, L., \& Francis, B. (2006). Understanding minority ethnic achievement: Race, gender, class and'success'. Routledge.

Shain, F. (2003). The Schooling and Identity of Asian Girls. Stoke-on-Trent:. Trentham Books.

Shain, F. (2013). 'The girl effect': Exploring narratives of gendered impacts and opportunities in neoliberal development. Sociological Research Online, 18(2), 1-11.

Shain, F. (2013). Race, nation and education: An overview of British attempts to 'manage diversity' since the 1950s. Education Inquiry, 4(1), 63-85.

Shain, F. (2017). Dangerous Radicals or Symbols of Crisis and Change: Re-theorising the Status of Muslim Boys as a Threat to the Social Order. In Muslim Students, Education and Neoliberalism (pp. 17-33). Palgrave Macmillan, London 
Bagguley, P., \& Hussain, Y. (2016). Negotiating mobility: South Asian women and higher education. Sociology, 50(1), 43-59.

Ball, S. J., Reay, D., \& David, M. (2002). 'Ethnic Choosing': Minority ethnic students, social class and higher education choice. Race ethnicity and education, 5(4), 333-357.

Ball, S., Macrae, S., \& Maguire, M. (2013). Choice, pathways and transitions post-16: New youth, new economies in the global city. Routledge.

Bhattacharyya, G., Ison, L., \& Blair, M. (2003). Minority ethnic attainment and participation in education and training: the evidence. Nottingham: Department for Education and Skills.

Boliver, V. (2013). How fair is access to more prestigious UK universities?. The British journal of sociology, 64(2), 344-364.

Brown, G. (2012). 'The Place of Aspiration In UK Widening Participation Policy: Moving Up or Moving Beyond?' In Critical Geographies of Childhood and Youth, edited by Peter Kraftl, John Horton and Faith Yucker, 97-113. London: Policy Press.

Cantle, T. (2001). Community cohesion. London: Home Office.

Casey, L. (2016). The Casey Review: A review into opportunity and integration.

Class, Gender and Education'. Gender and Education 15 (2): 115-132.

Crozier, G., \& Davies, J. (2006). Family matters: a discussion of the Bangladeshi and Pakistani extended family and community in supporting the children's education. The Sociological Review, 54(4), 678-695.

DCLG . (2009) The Turkish and Turkish Cypriot community in England: understanding Muslim ethnic communities. London: Department for Communities and Local Government

DfE (2019) Statistical first release

DfE. (2017). Unlocking Talent, Fulfilling Potential: A Plan for Improving Social Mobility through Education. 
Dwyer, C. (1999) 'Veiled Meanings: British Muslim Women and the Negotiation of Differences'. Gender, Place and Culture 6 (1): 5-26.

Elahi, F., and Khan, O. (2017). Islamophobia: Still a challenge for us all. London: Runnymede Trust. (Online), Retrieved from https://www.runnymedetrust.org/uploads/Islamophobia\%20 Report\%202018\%20FINAL.pdf (Accessed 30/07/2019)

Enneli, P., Modood, T., \& Bradley, H. (2005). Young Turks and Kurds: A set of'invisible' disadvantaged groups (pp. 1-59). York: Joseph Rowntree Foundation.

Farrell, F., \& Lander, V. (2019). "We're not British values teachers are we?": Muslim teachers' subjectivity and the governmentality of unease. Educational Review, 71(4), 466-482.

Farris, S. (2018).The Green Paper on the Integration of Women, Discover Society, 5:1

Gewirtz, S. (2001). Cloning the Blairs: New Labour's programme for the re-socialization of workingclass parents. Journal of Education Policy, 16(4), 365-378.

Gillborn, D. (2008). Racism and education: Coincidence or conspiracy?. Routledge.

Gillborn, D., \& Mirza, H. S. (2000). Educational Inequality: Mapping Race, Class and Gender. A Synthesis of Research Evidence.

Gillborn, D., \& Youdell, D. (1999). Rationing education: Policy, practice, reform, and equity. McGrawHill Education (UK).

Goldthorpe, J. H. (2016). Social class mobility in modern Britain: changing structure, constant process. Journal of the British Academy, 4(89-111).

HM Government. (2018). Integrated Communities Strategy Green Paper.London. HM Government.

Home Office. (2018). Hate Crime, England and Wales, 2018/19: Statistical Bulletin 20/18.London. HM Government. https://assets.publishing.service.gov.uk/government/uploads/system/uploads/attachment data/file 748598/hate-crime-1718-hosb2018.pdf

Home Office. (2019). Hate Crime, England and Wales, 2018/19: Statistical Bulletin 24/19, London, HM Government https://assets.publishing.service.gov.uk/government/uploads/system/uploads/attachment data/file 839172/hate-crime-1819-hosb2419.pdf 
Hussain, Y., \& Bagguley, P. (2007). Moving on up: South Asian women and higher education. Stokeon-Trent:Trentham Books Limited.

Khattab, N., \& Modood, T. (2018). Accounting for British Muslim's educational attainment: Gender differences and the impact of expectations. British Journal of Sociology of Education, 39(2), 242-259.

Kundnani, A. (2009). Spooked! How not to prevent violent extremism.

Lander, V. (Ed.). (2019). Fundamental British Values. Routledge.

Mac an Ghaill, M., Haywood, C., \& (2017). Muslim Students, Education and Neoliberalism. London: Palgrave Macmillan.

Maslen, J. (2019). Cracking the Code: The social mobility commission and education policy discourse. Journal of Education Policy, 34(5), 599-612.

Miah, S. (2017). Muslims, schooling and security. Springer International Publishing.

Mirza, H. S. (2009). Race, gender and educational desire: Why black women succeed and fail. Routledge.

Mirza, H. S. (2013, January). 'A second skin': Embodied intersectionality, transnationalism and narratives of identity and belonging among Muslim women in Britain. In Women's Studies International Forum (Vol. 36, pp. 5-15). Pergamon.

Mirza, H. S., \& Meetoo, V. (2018). Empowering Muslim girls? Post-feminism, multiculturalism and the production of the 'model' Muslim female student in British schools. British Journal of Sociology of Education, 39(2), 227-241.

Mirza, H. S., \& Reay, D. (2000). Spaces and places of black educational desire: Rethinking black supplementary schools as a new social movement. Sociology, 34(3), 521-544.

Modood, T. (2004). Capitals, ethnic identity and educational qualifications. Cultural trends, 13(2), 87105.

Modood, T. (2006). Ethnicity, Muslims and higher education entry in Britain. Teaching in Higher Education, 11(2), 247-250.. 
Modood, T., \& Khattab, N. (2016). Explaining ethnic differences: Can ethnic minority strategies reduce the effects of ethnic penalties?. Sociology, 50(2), 231-246..

Payne, G. (2017). The new social mobility: How the politicians got it wrong. Policy Press.

Pimlott-Wilson, H. (2015). Parental responsibility for paid employment and social reproduction: children's experiences in middle-class and working-class households in England. Environment and Planning A, 47(9), 1892-1906.

Raco, M. (2009). From expectations to aspirations: State modernisation, urban policy, and the existential politics of welfare in the UK. Political Geography, 28(7), 436-444..

Ramamurthy, A. (2006). The politics of Britain's Asian youth movements. Race \& Class, 48(2), 38-60.

Reay, D. (2013). Social mobility, a panacea for austere times: tales of emperors, frogs, and tadpoles. British Journal of Sociology of Education, 34(5-6), 660-677.

Reay, D., David, M., \& Ball, S. (2001). Making a difference?: Institutional habituses and higher education choice. Sociological Research Online, 5(4), 1-12.

Shah, B., Dwyer, C., \& Modood, T. (2010). Explaining educational achievement and career aspirations among young British Pakistanis: Mobilizing 'ethnic capital'?. Sociology, 44(6), 1109-1127.

Stevenson, J., Demack, S., Stiell, B., Abdi, M., Ghaffar, F., \& Hassan, S. (2017). The social mobility challenges faced by young muslims.

Tackey, N. D., Barnes, H., \& Khambhaita, P. (2011). Poverty, ethnicity and education. York: Joseph Rowntree Foundation.

Thapar, S., \& Sanghera, G. S. (2010). Building Social Capital and Education: The Experiences Of Pakistani Muslims in The UK. International Journal of Social Inquiry, 3(2).

Vincent, C. (2019). Cohesion, citizenship and coherence: schools' responses to the British values policy. British Journal of Sociology of Education, 40(1), 17-32. 
Women and Equalities Committee. (2016). Employment opportunities for Muslims in the UK. House of Commons, http://www. publications. parliament. uk/pa/cm201617/cmselect/cmwomeq/89/89. $p d f$.

Woodward, A. (2018). Exploring Economic inactivity through the Lived Experiences of British Pakistani Muslim Women.

Wright, C., Standen, P. J., \& Patel, T. (2009). Black youth matters: Transitions from school to success. Routledge.

Yosso, T. J. (2005). Whose culture has capital? A critical race theory discussion of community cultural wealth. Race ethnicity and education, 8(1), 69-91.

Zhou, M. (2005). Ethnicity as social capital: community-based institutions and embedded networks of social relations. Ethnicity, social mobility and public policy: comparing the US and UK, 131-159. 